\title{
Sikap Siswa Terhadap Pembelajaran Fisika di SMAN 2 Kota Sungai Penuh
}

\author{
Nadia Yensi Febriana*, Mashelin Wulandari \\ Program Studi Pendidikan Fisika, Universitas Jambi, Jambi, Indonesia \\ *Coresponding Author: nadiayensifebriana2001@gmail.com
}

Article History:

Received 2022-01-22

Revised 2022-02-12

Accepted 2022-03-03

DOI:

10.31949/educatio.v8i1.1939

\begin{abstract}
The purpose of this study was to determine students' attitudes towards learning physics, based on indicators of enjoyment in learning physics, interest in learning physics a lot, interest in a physics career, application of scientific attitudes, and social learning from physics. This research is a quantitative research using survey procedures through a questionnaire instrument (questionnaire) distributed on September 29, 2020. The sample used is 105 students consisting of class XI MIPA 2, XI MIPA 3, and XI MIPA 4 at SMAN 2 Kota Sungai Penuh. . The procedure in this research is carried out by distributing (questionnaire) to correspondents, analyzing data, and managing the data that has been obtained as a sample. In this study, it was applied because it was in accordance with the research objectives, where the aim was to find out the attitudes of high school students towards physics subjects. The results obtained from the overall indicator show a percentage of $83.3 \%$. Based on these results, it can be said that students' attitudes towards learning physics are categorized as good.

Keywords: education; student attitudes; scientifics attitudes, physics; interest in physics
\end{abstract}

\begin{abstract}
Abstrak
Tujuan dari penelitian ini adalah untuk mengetahui sikap siswa terhadap pembelajaran Fisika, berdasarkan indikator kesenangan dalam belajar fisika, ketertarikan memeperbanyak waktu belajar fisika, ketertarikan berkarir dibidang fisika, adopsi sikap ilmiah, dan implikasi sosial dari fisika. Penelitian ini berjenis penelitian kuantitatif menggunakan prosedur survei melalui instrumen kuesioner (angket) yang disebar pada tanggal 29 September 2020. Sampel yang digunakan sebanyak 105 Siswa yang terdiri dari kelas XI MIPA 2, XI MIPA 3, dan XI MIPA 4 di SMAN 2 Kota Sungai penuh. Prosedur dalam penelitian ini dilakukan dengan cara menyebarkan kuesioner (angket) kepada koresponden, menganalisis data, dan mengelola data yang telah didapatkan yang menjadi sampel. Pada penelitian ini diterapkan karena sesuai dengan tujuan penelitian, dimana tujuannya adalah mengetahui Sikap Siswa SMA terhadap mata pelajaran Fisika. Hasil yang diperoleh dari indikator secara keseluruhan menunjukkan persentase sebesar $83,3 \%$. Berdasarkan hasil tersebut dapat disimpulkan bahwa sikap siswa terhadap pembelajaran fisika berkategori baik.

Kata Kunci: pendidikan; sikap siswa; sikap ilmiah; fisika; ketertarikan di bidang fisika
\end{abstract}

\section{PENDAHULUAN}

Pendidikan sangat berperan penting dalam kehidupan, karena dengan adanya pendidikan seseorang mampu menem-patkan dirinya dengan layak di lingkungan keluarga maupun masyarakat (Astalini, Kurniawan, \& Putri, 2018). Pendidikan adalah salah satu bentuk perwuju dan kebudayaan manusia yang dinamis dan sarat perkembangan (Dwijayanti \& Pathoni, 2016). Pendidikan tidak hanya tentang ilmu pengetahuan, melainkan juga tentang pembentukan karakter atau sikap siswa. Banyak sekali usaha yang dilakukan pemerintah Indonesia untuk memajukan pendidikannya. Salah satunya yaitu dengan membuat Kurikulum baru (Tiara \& Sari, 2019). Fisika pada kenyataannya menjadi salah satu mata pelajaran yang dianggap berat dan dihindari oleh sebagian peserta didik karena membutuhkan ketekunan, keseriusan dan banyak latihan. "Physics is considered difficult learning for students from high school to university as well as for postgraduate education" (Jufrida et al., 
2019). Artinya Fisika masih dianggap sulit bagi siswa terutama karena pembelajaran berlangsung secara konvensional dimana siswa diharuskan menghafalkan rumus-rumus yang abstrak (Astalini, Kurniawan, \& Sumaryanti, 2018). Siswa juga belum memiliki kemauan untuk mengemukakan pendapat sewaktu berlangsungnya proses pembelajaran kecuali siswa yang cukup pintar di kelas tersebut sedangkan siswa yang kurang berprestasi hanya diam saja. Siswa lebih banyak mendengarakan penjelasan yang disampaikan oleh guru (Khodijah et al., 2016).

Sikap dalam penelitian Umpang \& Munawar (2018) merupakan salah satu faktor yang mempengaruhi proses pembelajaran dan sangat berpengaruh terhadap hasil belajar yang akan diperoleh siswa. Setiap siswa memiliki karakteristik yang berbeda, begitu juga kecendurungan sikap yang dimilikinya. Sebagaimana yang kita ketahui, pembelajaran merupakan segala usaha yang dilakukan seorang pendidik agar terjadi belajar pada diri siswanya.

Sikap berperan penting dalam proses pembelajaran, salah satunya sikap dalam pembelajaran IPA (Wiza, 2019). Sikap itu berasal dari dalam diri peserta didik itu sendiri, yaitu perasaan terhadap suatu objek yang diperlihatkan dalam perasaan suka ataupun tidak suka (Astalini et al., 2019).Dalam hal dinyatakan dalam penelitian (Asrial et al., 2019) "The teacher who makes great activation of his roles in classroom management and enriches learners' knowledge" artinya guru sangat berperan penting dalam menumbuhkan sikap siswa.

Sikap merupakan suatu kemampuan penilaian sesuatu yang dicerminkan dengan sikap menerima, menolak, atau mengabaikan.5 Sikap siswa terhadap pembelajran sains pada kelompok heterogen tidak dipengaruhi oleh budaya dan latar belakang yang berbeda (Kurniawan et al., 2018). Hadis dan Nurhayati (2014) dalam Sitompul et al (2018) menyatakan bahwa bahwa siswa yang memiliki motivasi belajar tinggi itulah yang menunjukkan sikap dan perilaku belajar yang baik berupa melakukan aktivitas belajar.

Sikap belajar siswa akan terwujud dalam bentuk perasaan senang atau tidak senang, setuju atau tidak setuju, suka atau tidak suka terhadap hal-hal tersebut. Sikap seperti ini akan berpengaruh terhadap proses dan hasil belajar yang dicapainya. Sesuatu yang menimbulkan rasa senang, cenderung akan diulang, demikian menurut hukum belajar law of effect. Sikap itu berperan dalam proses pembelajaran siswa, karena apabila siswa memiliki sikap yang baik, maka juga akan memiliki hasil belajar yang baik, begitupun sebaliknya, hal ini sejalan dengan yang di kemukakan oleh (Astalini et al., 2019), sikap sangat penting dalam proses berlangsungnya pembelajaran. Karena jika peserta didik memiliki sikap negatif terhadap pelajaran fisika, maka mereka juga akan bersikap negatif terhadap guru fisika.

Selain itu, Rijal \& Bachtiar (2015)juga mengemukakan bahwa, sikap siswa berperan sebagai penunjang dalam mencapai suatu tujuan pembelajaran. Sikap dipengaruhi perasaan pendukung atau tidak mendukung terhadap suatu objek. Terdapat banyak asumsi bahwa ada hubungan yang positif antara sikap siswa dengan hasil belajarnya. Dengan kata lain, bahwa siswa yang mempunyai sikap positif terhadap pelajaran tertentu cenderung lebih tekun dalam belajar sehingga mencapai hasil yang memuaskan. Dan sebaliknya, siswa yang mempunyai sikap negatif terhadap pelajaran, dia tidak akan bersemangat belajar sehingga hasilnya kurang memuaskan. Sikap positif ini diartikan sikap yang dapat mendukung siswa dalam mempelajari biologi, seperti menyenangi pelajaran tersebut dan sikap yang negatif merupakan sikap yang menghambat dalam mempelajari biologi.

Menurut Luthans didalam Hanurawan (2015) menjelaskan empat fungsi sikap yaitu : fungsi penyesuaian diri, berarti bahwa orang cenderung mengembangkan sikap yang akan membantu untuk mencapai tujuannya secara maksimal; fungsi pertahanan diri mengacu pada pengertian bahwa sikap dapat melindungi seseorang dari keharusan untuk mengakui kenyataan tentang dirinya; fungsi ekspresi nilai bearti bahwa sikap membantu ekspresi positif nilai-nilai dasar seseorang, memamerkan citra dirinya, dan aktualisasi diri; fungsi pengetahuan bearti bahwa sikap membantu seseorang menetapkan standar evaluasi terhadap sesuatu hal. Standar itu menggambarkan keteraturan, kejelasan, dan stabilitas kerangka acu pribadi seseorang dalam menghadapi objek atau peristiwa di sekelilingnya

Ada beberapa faktor yang mempengaruhi hasil belajar salah satunya adalah sikap. Sikap merupakan sesuatu yang dipelajari, dan sikap menentukan bagaimana individu bereaksi terhadap situasi serta menentukan apa yang dicari indivdu dalam kehidupan (Atiaturrahmaniah \& Rahayu, 2018). Selain dengan adanya sikap 
ilmiah, siswa sangat memerlukan konsentrasi yang cukup jika mempelajari Fisika, karena siswa menganggap bahwa fisika itu sulit. Sehingga konsentrasi sangat diperlukan dalam pengoptimalan pembelajaran. Konsentrasi yang dimaksud adalah untuk memusatkan perhatian pada situasi belajar yang dirancang duru sehingga semua sumber daya mental untuk belajar (Puspitasari et al., 2019)

Peneliti memilih melakukan penelitian tentang sikap siswa terhadap pembelajaran fisika ini dikarenakan belum ditemukannya penelitian yang sama dengan penelitian peneliti ini terlebih lagi di SMAN 2 Kota Sungai Penuh. Sehingga peneliti tertarik untuk melaksanakan penelitian ini dengan harapan hasilnya dapat dijadikan referensi dan acuan untuk peneliti lai ataupun guru dalam menilai sikap siswa terhadap pembelajaran fisika. Tujuan dari penelitian ini yaitu untuk mengetahui sikap yang dimiliki oleh siswa terhadap pembelajaran fisika.

\section{METODE PENELITIAN}

Jenis Penelitian yang digunakan adalah Penelitian Kuantitatif yang menggunakan rancangan penelitiannya adalah Penelitian Survei. Penelitian kuantitatif merupakan penelitian yang terstruktur dan mengkuantifikasikan data sehingga data dapat dijadikan sebuah hasil dari sebuah penelitian (Wiza, 2019). Penelitian kuantitatif biasanya menggunakan desain eksplanasi, di mana objek telaahan penelitian eksplanasi (explanatory research) adalah untuk menguji hubungan antar-variabel yang dihipotesiskan. Pada jenis penelitian ini, jelas ada hipotesis yang akan diuji kebenarannya. Hipotesis itu sendiri menggambarkan hubungan antara dua atau lebih variabel; untuk mengetahui apakah sesuatu variabel berasosiasi ataukah tidak dengan variabel lainnya; atau apakah sesuatu variabel disebabkan/dipengaruhi ataukah tidak oleh variabel lainnya

Pada penelitian ini diterapkan karena sesuai dengan tujuan penelitian, dimana tujuannya adalah mengetahui Sikap Siswa SMA terhadap mata pelajaran Fisika. Sampel yang digunakan berasal dari 105 Siswa SMAN 2 Kota Sungai Penuh yang berlokasi di Provinsi Jambi dengan menggunakan purposive sampling. Pupposive sampling adalah teknik pengambilan sampel berdasarkan kriteria dari peneliti (Kerlinger, 2014). Dimana sampel adalah bagian dari jumlah dan karakteristik yang dimiliki oleh populasi tersebut (Pradana \& Reventiary, 2016).

Tabel 1. Indikator Sikap Terhadap Mata Pelajaran Fisika

\begin{tabular}{|c|c|c|c|c|}
\hline \multirow{2}{*}{ Variabel } & \multirow{2}{*}{ Indikator } & \multicolumn{2}{|c|}{ Pernyataan } & \multirow{2}{*}{ Jumlah } \\
\hline & & $(+)$ & $(-)$ & \\
\hline \multirow{5}{*}{$\begin{array}{l}\text { Sikap pada Mata } \\
\text { Pelajaran Fisika }\end{array}$} & $\begin{array}{l}\text { Kesenangan dalam } \\
\text { belajar fisika }\end{array}$ & $1,2,3$ & 4,5 & 5 \\
\hline & $\begin{array}{l}\text { Ketertarikan } \\
\text { memperbanyak waktu } \\
\text { belajar fisika }\end{array}$ & $6,7,8$ & 09.10 & 5 \\
\hline & $\begin{array}{l}\text { Ketertarikan berkarir } \\
\text { dibidang fisika }\end{array}$ & $11,12,13,15$ & 14 & 5 \\
\hline & $\begin{array}{l}\text { Adopsi dari sikap } \\
\text { ilmiah }\end{array}$ & $16,17,18$ & 19,2 & 5 \\
\hline & $\begin{array}{l}\text { Implikasi social dari } \\
\text { fisika }\end{array}$ & $21,22,23$ & 24,25 & 5 \\
\hline
\end{tabular}

Teknik pengumpulan data yang digunakan dalam penelitian ini ialah kuesioner (angket) yang di adopsi dari Rio Damawangsa (2018) pada penelitian yang disebar pada tanggal 29 September 2020 pada jam 10.30 wib. Kuesioner merupakan dokumen yang berisi pertanyaan untuk memperoleh informasi yang hendak didapatkan, dimana kuesioner cocok digunakan dalam penelitian survey. Kuesioner cocok digunakan untuk penelitian kuantitatif maupun kualitatif dengan metode pengumpulan data seperti ini disebut survey. Berdasarkan pengertian di atas dapat disimpulkan bahwa angket (kuesioner) merupakan alat pengumpul data yang berisi kumpulan pernyataan yang diberikan kepada responden untuk memberikan respon terhadap pernyataan tersebut. Menurut Hardiyanti et al (2018), tujuan penyebaran angket ialah mencari informasi yang lengkap mengenai suatu masalah dari responden tanpa merasa khawatir bila responden memberi jawaban yang tidak sesuai pernyataan dalam pengisian daftar pertanyaan. 
Pada penelitian ini, peneliti menggunakan 4 indikator yang menggunakan skala likert 4 (empat) (untuk pernyataan positif Sangat Tidak Setuju memiliki skor 1, Tidak Setuju memiliki skor 2, Setuju memiliki skor 3 dan Sangat Setuju 4. Untuk pernyataan negatif Sangat Tidak Setuju memiliki skor 4, Tidak Setuju memiliki skor 3, Setuju memilki skor 2 dan Sangat Setuju memiliki skor 1. Skala likert adalah skala yang dapat dipergunakam untuk mengukur sikap, pendapat, atau presepsi seseorang atau sekelompok orang tentang satu variabel, konsep atau gejala atau fenomena pendidikan.

Prosedur dalam penelitian ini dilakukan dengan cara menyebarkan kuesioner (angket) kepada koresponden, menganalisis data, dan mengelola data yang telah didapatkan yang menjadi sampel. Analisis data menggunakan program SPSS untuk mencari hasil kuantitatif yang digunakan oleh peneliti dan berguna untuk mencari hasil dari statistik deskriptif. Menurut Wiza (2019), penelitian deskriptif mengarah kepada masalah yang terjadi pada masyarakat, seperti hubungan, sikap, pandangan, dan pengaruh dari susatu fenomena. Data analysis in this study used descriptive statistics. Descriptive statistics used by researchers to describe sample data.

\section{HASIL DAN PEMBAHASAN}

Penelitian ini dilaksanakan di SMAN 2 Kota Sungai Penuh pada semester ganjil tahun 2020/2021 dengan tujuannya adalah mengetahui Sikap Siswa SMA terhadap mata pelajaran Fisika.

\section{Kesenangan dalam belajar fisika}

\begin{tabular}{|c|c|c|c|c|c|c|c|c|}
\hline Indikator & Rentang & Kategori & Mean & Median & Min & Max & $\%$ & $\mathrm{f}$ \\
\hline \multirow{4}{*}{$\begin{array}{l}\text { Kesenangan } \\
\text { dalam belajar } \\
\text { Fisika }\end{array}$} & $5-8,75$ & Sangat Tidak Setuju & \multirow{4}{*}{14,229} & \multirow{4}{*}{14} & \multirow{4}{*}{7} & \multirow{4}{*}{19} & 9 & 1 \\
\hline & $8,76-12,5$ & Tidak Setuju & & & & & 10,9 & 12 \\
\hline & $12,51-16,25$ & Setuju & & & & & 73,6 & 81 \\
\hline & $16,26-20$ & Sangat Setuju & & & & & 10 & 11 \\
\hline
\end{tabular}

Kesenangan dalam Kamus Besar Bahasa Indonesia adalah perihal senang; kepuasan; keenakan; kebahagiaan; kelegaan; kegemaran; dan kesukaan. Proses pembelajaran yang menyenangkan terlihat saat secara aktif dalam pembelajaran (Fitriani et al., 2020). Dalam hal ini, sejalan dengan Astalini, Kurniawan, \& Sumaryanti (2018) bahwa kesenangan dalam belajar fisika berarti perasaan suka siswa dalam pelajaran fisika yang diikuti dengan rasa ingin tahu yang tinggi.

Berdasarkan hasil data statistik dapat dilihat siswa memiliki sikap sangat tidak baik sebanyak 9\% (1 dari 105 siswa), tidak baik 10,9\% (12 dari 105 siswa), baik 73,6\% (81 dari 105 siswa), sangat baik 10\% (11 dari 105 siswa. sehingga sehingga dapat disimpulkan bahawa siswa SMA Negeri 2 Kota Sungai Penuh yang terdiri dari kelas XII MIPA 2. XII MIPA 3, dan XII MIPA memiliki sikap kesenangan terhadap fisika dengan kategori baik sebesar 73,6\% dari total keseluruhan.

\section{Ketertarikan Memperbanyak Waktu Belajar IPA}

Tabel 3. Ketertarikan Memperbanyak Waktu Belajar IPA.

\begin{tabular}{|c|c|c|c|c|c|c|c|c|}
\hline Indikator & Rentang & Kategori & Mean & Median & Min & Max & $\%$ & $\mathrm{f}$ \\
\hline $\begin{array}{l}\text { Ketertarikan } \\
\text { Memperbanyak }\end{array}$ & $5-8,75$ & $\begin{array}{ll}\text { Sangat } & \text { Tidak } \\
\text { Setuju } & \end{array}$ & & & & & 9 & 1 \\
\hline Waktu Belajar & $8,76-12,5$ & Tidak Setuju & 13,07619 & 13 & 8 & 20 & 25 & 28 \\
\hline \multirow[t]{2}{*}{ IPA } & $12,51-16,25$ & Setuju & & & & & 63,4 & 78 \\
\hline & $16,26-20$ & Sangat Setuju & & & & & 4,5 & 5 \\
\hline
\end{tabular}

Penambahan waktu belajar memungkinkan siswa dapat mengulang kembali materi pembelajarannya. Siswa dapat meningkatkan penguasaan materi pelajarannya dengan mengulang mempelajari materi pembelajaran beberapa kali, melatih soal- soal baik secara mandiri maupun berkelompok. Berdasarkan hal 
tersebut, jika siswa sudah memiliki sikap seperti senang dan tertarik untuk meluangkan waktu terhadap pembelajaran fisika, maka selanjutnya akan menetap dan melanjutkan karirnya dalam bidang Fisika juga. Ketertarikan untuk melanjutkan karir dibidang Fisika tidak lepas dari seberapa besar individutersebut memiliki keyakinan bahwa berkarir dibidang fisika merupakan salah satu keinginan untuk masa depannya. Dengan kata lain, ketertarikan berkarir dalam bidang fisika dapat meningkatkan sikap siswa terhadap fisika (Putra et al., 2019).

Berdasarkan hasil data statistik dapat dilihat siswa memiliki sikap ketertarikan memperbanyak waktu belajar Fisika dengan persentase sangat tidak baik sebanyak 9\% (1 dari 105 siswa), tidak baik 25\% (28 dari 105 siswa), baik 63,4\% (78 dari 105 siswa), sangat baik 4,5\% (5 dari 105 siswa. Sehingga sehingga dapat disimpulkan bahawa siswa SMA Negeri 2 Kota Sungai Penuh yang terdiri dari kelas XII MIPA 2. XII MIPA 3, dan XII MIPA memiliki sikap memperbanyak waktu belajar Fisika dengan kategori baik sebesar 63,4 \% dari total keseluruhan yaitu 105 orang siswa.

\section{Ketertarikan Berkarir dibidang Fisika}

Tabel 4. Ketertarikan Berkarir dibidang Fisika

\begin{tabular}{|c|c|c|c|c|c|c|c|c|}
\hline Indikator & Rentang & Kategori & Mean & Median & Min & Max & $\%$ & $\mathrm{f}$ \\
\hline \multirow{4}{*}{$\begin{array}{l}\text { Ketertarikan } \\
\text { Berkarir } \\
\text { dibidang Fisika }\end{array}$} & $5-8,75$ & $\begin{array}{ll}\text { Sangat } & \text { Tidak } \\
\text { Setuju } & \end{array}$ & \multirow{4}{*}{13,87619} & \multirow{4}{*}{14} & \multirow{4}{*}{9} & \multirow{4}{*}{19} & 0 & 0 \\
\hline & $8,76-12,5$ & Tidak Setuju & & & & & 19,8 & 22 \\
\hline & $12,51-16,25$ & Setuju & & & & & 70,3 & 78 \\
\hline & $16,26-20$ & Sangat Setuju & & & & & 4,5 & 5 \\
\hline
\end{tabular}

Ketertarikan berkarir dibidang fisika merupakan suatu keinginan untuk melanjutkan studi dibidang fisika (Putra et al., 2019). Berdasarkan hasil data statistik dapat dilihat siswa memiliki sikap ketertarikan berkarir dibidang Fisika dengan persentase sangat tidak baik sebanyak 0\%, tidak baik 19,8\% (22 dari 105 siswa), baik 70\% (78 dari 105 siswa), sangat baik 4,5\% (5 dari 105 siswa. sehingga dapat disimpulkan bahawa siswa SMA Negeri 2 Kota Sungai Penuh yang terdiri dari kelas XII MIPA 2. XII MIPA 3, dan XII MIPA memiliki sikap ketertarikan berkarir di bidang fisika dengan kategori baik sebesar 70,3\% dari total keseluruhan. Hal ini menunjukkan bahwa masih ada keraguan dari siswa di SMA Negeri 2 Kota Sungai Penuh untuk melanjutkan karirnya dibidang fisika.

\section{Adopsi dari Sikap Ilmiah}

Tabel 5. Adopsi dari Sikap Ilmiah

\begin{tabular}{|c|c|c|c|c|c|c|c|c|}
\hline Indikator & Rentang & Kategori & Mean & Median & Min & Max & $\%$ & $\mathrm{f}$ \\
\hline & $5-8,75$ & Sangat Tidak Setuju & \multirow{4}{*}{13,67619} & \multirow{4}{*}{13} & \multirow{4}{*}{11} & \multirow{4}{*}{19} & 0 & 0 \\
\hline & $8,76-12,5$ & Tidak Setuju & & & & & 9,6 & 11 \\
\hline & $12,51-16,25$ & Setuju & & & & & 79,1 & 91 \\
\hline & $16,26-20$ & Sangat Setuju & & & & & 2,6 & 3 \\
\hline
\end{tabular}

Menurut (Efendi et al., 2020), adopsi dari sikap ilmiah memuat tentang sikap ilmiah yang harus diterapkan oleh siswa dalam mempelajari fisika. Orang yang berfikir secara ilmiah cenderung untuk mendedikasikan dirinya untuk tugas penemuan-penemuan dan kreativitas. Komponen utama yang ada dalam sikap ilmiah yaitu keyakinan, perasaan dan tindakan. Berdasarkan hasil data statistik dapat dilihat siswa memiliki sikap adopsi dari sikap ilmiah dengan persentase sangat tidak baik sebanyak 0\%, tidak baik $9,6 \%(11$ dari 105 siswa), baik 79,1\% (91 dari 105 siswa), sangat baik 2,6\% (3 dari 105 siswa. sehingga siswa SMA Negeri 2 Kota Sungai Penuh yang terdiri dari kelas XII MIPA 2. XII MIPA 3, dan XII MIPA memiliki sikap adopsi dari sikap ilmiah dengan kategori baik sebesar 79,1\% dari total keseluruhan. 


\section{Implikasi Sosial dari Fisika}

Tabel 6. Implikasi Sosial dari Fisika

\begin{tabular}{lllllllll}
\hline Indikator & Rentang & Kategori & Mean & Median & Min & Max & $\%$ & $\mathrm{f}$ \\
\hline $5-8,75$ & Sangat Tidak Setuju & & & & & 9 & 1 \\
& $8,76-12,5$ & Tidak Setuju & \multirow{214,7619}{*}{15} & 6 & 22 & 10,3 & 11 \\
$12,51-16,25$ & Setuju & & & & & 71 & 76 \\
$16,26-20$ & Sangat Setuju & & & & & 14 & 15 \\
\hline
\end{tabular}

Implikasi sosial dari IPA menggambarkan bagaimana siswa menrapkan apa yang mereka pelajari dari IPA dalam kehidupan social (Kurniawan et al., 2018). Pada table 5 mengungkapkan bahwa sikap siswa berdasarkan implikasi sosial dari IPA memiliki kategori baik dengan Mean 14,7619 dan Median 15. Dari hasil mean dan modus ini mengungkapkan bahwa sikap siswa terhadap indicator implikasi social dari IPA termasuk dalam kategori baik. Selanjutnya juga didukung dari hasil analisis data pada Tabel 1 juga mengungkapkan bahwa 1\% (9 dari 105) siswa dalam kategori sangat tidak baik, 10,3\% (11 dari 105 siswa) dalam kategori tidak baik, 71\% (76 dari 105 siswa) dalam kategori baik, dan 14\% (15 dari 105 siswa) dalam kategori sangat tidak baik.

Pada indikator berkarir di bidang IPA terlihat bahwa siswa di SMAN 2 Kota Sungai Penuh ini sangat peduli akan karirnya di bidang IPA. Dari hasil tersebut siswa menjadi termotivasi untuk memberikan ilmu yang dia dapat untuk di sampaikan kepada orang lain salah satunya pada bidang pendidikan. Hal ini sejalan dengan Wiza (2019) bahwa untuk berkarir di bidang IPA ini tidak lepas dari keterampilan proses, dimana keterampilan proses ini dapat membuat seseorang menggunakan ide serta kreatif kedepannya.

\section{KESIMPULAN}

Berdasarkan hasil penelitian dan pembahasan tentang sikap siswa terhadap pembelajaran fisika di kelas XII MIPA 2, XII MIPA 3, dan XII MIPA 4 di SMA Negeri 2 Kota Sungai Penuh sebanyak 105 responden, hasil yang diperoleh dari indikator secara keseluruhan menunjukkan persentase sebesar 83,3\%, maka dapat ditarik kesimpulan bahwa sikap siswa SMAN 2 Kota Sungai Penuh terhadap pembelajaran fisika berkategori baik. Berdasarkan pembahasan dan kesimpulan, maka saran yang dapat disampaikan oleh peneliti adalah Tindak lanjut dan pengelolaan hasil penilaian sikap sebagian siswa yang masih kurang baik dapat berupa cara berupa teguran, bimbingan, nasehat, dan membuat surat perjanjian, agar proses pembelajaran kedepannya lebih efektif.

\section{DAFTAR PUSTAKA}

Asrial, Syahrial, Kurniawan, D. A., \& Anandari, Q. S. (2019). Digitalization of Ethno Constructivism Based Module for Elementary School Students. Jurnal Ilmu Pendidikan (IP), 25(1), 33-41.

Astalini, Kurniawan, D. A., Perdana, R., \& Pathoni, H. (2019). Identifikasi Sikap Peserta Didik Terhadap Mata Pelajaran Fisika di Sekolah Menengah Atas Negeri 5 Kota Jambi. Unnes Physics Education Journal, 8(1), 34-43.

Astalini, Kurniawan, D. A., \& Putri, A. D. (2018). Identifikasi sikap implikasi sosial dari ipa, ketertarikan menambah waktu belajar ipa, dan ketertarikan berkarir dibidang ipa siswa SMP se-Kabupaten Muaro Jambi. Jurnal Tarbiyab: Jurnal Ilmiah Kependidikan, 7(2), 93-108.

Astalini, Kurniawan, D. A., \& Sumaryanti. (2018). Sikap Siswa Terhadap Pelajaran Fisika di SMAN Kabupaten Batanghari. Jumal Ilmu Pendidikan Fisika, 3(2), 59-64.

Atiaturrahmaniah, \& Rahayu, S. (2018). Hubungan Sikap Matematika dengan Hasil Belajar Siswa Kelas V SDN 06 Montong Baan. Jurnal DIDIKA: Wahana Ilmiah Pendidikan Dasar, 4(2), 58-65.

Dwijayanti, E., \& Pathoni, H. (2016). Penerapan Strateri Pembelajaran Aktif Tipe Peer Lesson Untuk 
Meningkatkan Aktivitas dan Hasil Belajar Siswa Pada Materi Suhu dan Kalor Kelas XA di SMAN 8 Kota Jambi. Jurnal EduFisika, 01(01), 18-21.

Efendi, R., Puspitasari, T. O., \& Pratiwi, N. I. S. (2020). Identifikasi Sikap Implikasi Sosial dari Fisika, Normalitas Ilmuawan, dan Adopsi Sikap Ilmiah. Attractive : Innovative Education Journal, 2(1), 132-142.

Fitriani, R. S., Puspitasari, T. O., \& Melisa, D. (2020). Deskripsi Sikap Siswa Dalam Kesenangan Belajar Fisika dan Ketertarikan Memperbanyak Waktu Belajar Fisika di SMAN Batanghari. JIFP (Jurnal Ilmu Fisika Dan Pembelajarannya), 4(1), 1-5.

Hardiyanti, K., Astalini, \& Kurniawan, D. A. (2018). Sikap Siswa Terhadap Mata Pelajaran Fisika di SMA Negeri 5 Muaro Jambi. JUrnal EduFisika, 3(2), 1-12.

Jufrida, J., Kurniawan, W., Astalini, A., Darmaji, D., Kurniawan, D. A., \& Maya, W. A. (2019). Students' Attitude and Motivation in Mathematical Physics. International Journal of Evaluation and Research in Education (IJERE), 8(3), 401-408. https:// doi.org/10.11591/ijere.v8i3.20253

Khodijah, D. N., Hendri, M., \& Darmaji. (2016). Upaya Meningkatkan Partisipasi dan Hasil Belajar dengan Menggunakan Model Pembelajaran Kooperatif Tipe Think Pair Share di Kelas XI MIA 7 SMAN 1 Muaro Jambi. Jurnal EduFisika, 01(02), 46-54.

Kurniawan, D. A., Astalini, \& Anggraini, L. (2018). Evaluasi Sikap Siswa SMP Terhadap IPA di Kabupaten Muaro Jambi. Jumal Ilmiah DID AKTIKA, 19(1), 124-139.

Pradana, M., \& Reventiary, A. (2016). Pengaruh Atribut Produk Terhadap Keputusan Pembelian Sepatu Merek Customade (Studi di Merek Dagang Customade Indonesia). Jurnal Manajemen, 6(1), 1-10.

Puspitasari, T. O., Putri, Y. E., \& Yohanes. (2019). Sikap Terhadap Konsentrasi Belajar Siswa Pada Mata Pelajaran Fisika di Sekolah Menengah Atas. JIPFRI (Jumal Inovasi Pendidikan Fisika Dan Riset Ilmiah), 3(2), 79-85.

Putra, D. S., Lumbantoruan, A., \& Samosir, S. C. (2019). Deskripsi Sikap Siswa: Adopsi Sikap Ilmiah, Ketertarikan Memperbanyak Waktu Belajar Fisika dan Ketertarikan Berkarir di Bidang Fisika. Tarbiyab: Jurnal Ilmiah Kependidikan, 8(2), 91-100.

Rijal, S., \& Bachtiar, S. (2015). Hubungan antara Sikap , Kemandirian Belajar , dan Gaya Belajar dengan Hasil Belajar Kognitif Siswa. Jumal BIOEDUKATIKA, 3(2), 15-20.

Sitompul, R. S., Astalini, \& Alrizal. (2018). Deskripsi Motivasi Belajar Fisika Siswa Kelas X MIA di SMAN 9 Kota Jambi. Jurnal EduFisika, 3(2), 22-31.

Tiara, S. K., \& Sari, E. Y. (2019). Analisis Teknik Penilaian Sikap Sosial Siswa Dalam Penerapan Kurikulum 2013 di SDN 1 Watulimo. EduHumaniora: Jumal Pendidikan Dasar, 11(1), 21-30.

Umpang, M. D., \& Munawar, T. (2018). Analisis Sikap Belajar Siswa Pada Mata Pelajaran IPS Terpadu SMP Negeri 02 Tempunak. Jurnal Pendidikan Ekonomi, 3(1), 47-57.

Wiza, O. H. (2019). Implikasi sikap sosial, minat menambah jumlah waktu belajar, dan ketertarikan berkarir di bidang IPA. 6(2), 86-93. 